\title{
Impacts of Redenomiantion on Economics Indicators
}

\author{
Prof. Dr. Euphrasia Susy Suhendra (Gunadarma University, Indonesia) \\ Sri Wayhu Handayani (Gunadarma University, Indonesia)
}

\begin{abstract}
The purpose of this study is to examine the impacts of redenomination on inflation, currency exchange, economic growth and export value. While decisions on redenomination and design of currencies may seem more technical than political, a government's control and administration of its currency and transactions within its boundaries are a few examples of the hallmarks of the modern nation-state. In this study, there are 27 countries which are involved in redenominating their currencies. The datas that are analyzed are rate of inflation, exchange rate, economic growth and export value which are obtained from the World Bank. Independent sample T-test was performed to analyze the impacts of redenomination on the mentioned variables. Result of the study indicates that inflation and economic growth were affected significantly by redenomination.
\end{abstract}

JEL codes: E01, E31

\section{Introduction}

Currency redenomination is a public policy measure that simplifies the understanding, use and management of the national currency through its expression in a new and smaller equivalent scale. In other words, the currency redenomination does an elimination of a specific number of zeroes from the currency, and brings everything that is expressed through the national currency to that new monetary scale. It involves all amounts: prices of goods and services sold in the country, wages and salaries, savings, pensions, debts, rents, and other commited payments, exchange rate and taxes, and others (Venezuelle, 2008, p.9).

In times of inflation, the same amount of monetary units has slowly weakened purchasing power. In other words, the price of products and services must be written with a larger amount. When these numbers are getting bigger, they can affect daily transactions because of the risks and discomfort which are caused by a number of bills that must be taken, or because of human psychology that is not effective in handling a large calculation. The authorities can minimize this problem by conducting redenomination: The new unit replaces the old unit with a certain number of units of the old converted into a new unit. If the reason of redenomination is inflation, the conversion ratio can be greater than 1, usually a positive number multiple of ten, such as $10,100,1,000$, and so on. This procedure can be referred as "the removal of zero.

The redenomination also will affect the financial and accounting from a State which has made redenomination. The impact that occurs is not directly on the economy. It is because the value of money will remain the same and there is an equal purchasing power. The real impact on the economy in terms of micro and macro will be zero. Demand and supply of goods and services will not change, net investment, government spending, net exports balance of payments will experience a change of cosmic which do not have any economic impact, and at the level of household consumption.

According to Mosley (2005), the reasons in which some countries decide to redenominate their currency are a combination of economic and political factors such as inflation, government concerns about credibility and the effect of currency on national identity. The author also stated that the redenomination is also related to other political variables such as government time horizons, the governing party's ideology, the fractionalization of government and legislature and the degree of social heterogeneity.

Finally, many nations with high levels of inflation also have relatively lower valued local currencies , making large denominated currencies 'necessary for basic transactions in the economy'(Layner 2006 cited in Thesis). The Hypotheses of this study states that inflation is an important predictor of model and application of redenomination due to relatively high inflation rates which make local currency has no value, and make big value of currency denomination is required for basic transactions in the economy. Akinboade, Siebrits and Roussot (2006) state that "low inflation is taken to be a sign of internal economic stability in the host country. High inflation indicates the inability of the government to balance its budget and the failure of the central bank to conduct appropriate monetary policy." In other words, inflation can be used as an indicator of the economic and political conditions of the host country, but the differences between "high" inflation and "low" inflation is not distinct.

The aim of this study has a two-fold purpose: to determine and analyze at which macroeconomic factor has the largest influence on the occurrence of redenomination.

\section{Redenomination and Macro Economics Indicator}

Redenomination of a country's currency is a policy decision that is aimed at making the use, understanding and management of a currency more efficiently by expressing the units of the currency in new but equivalent 
smaller scale. Thus redenomination takes place when a country's currency units are restored to a new set of units based on a certain ratio mainly due to inflation and currency devaluation. Pressure from inflation depreciates the value of money which depends on the speed of occurrence and consequently the corresponding prices of the goods and services which an erstwhile amount of money can buy appears larger than it was and is thus expressed. The more the inflation, the higher the numbers which express the prices that may eventually begin to affect the smoothness of everyday transactions (Oluba, 2008:2).

There are many reasons behind a country that decides to do redenomination of its currency, ranging from credibility and identity to domestic and international politics. Specifically, though it is not exhaustive, inflationary pressures, psychological effect, control of currency substitution and domestic politics are identified as the main reasons of redenomination (Cohen, 2004; Mosley, 2005; Tarhan, 2006). Günal (2000) states that removing zeros from currency is a complementary component of policy stabilization and it will have positive physiologic effects on restoring the credibility of this currency and on reducing inflationary expectations as well as enhancing the ease of transaction and calculation.

Currency redenomination can also indicates the attempt of governments to reassert monetary sovereignty. If citizens lose confidence in the national currency, they may begin to use foreign currencies; particularly for those with greater prestige. This may be both a psychological and an economic blow to the government: with widespread foreign currency substitution (or, more extremely, full dollarization), the central bank no longer controls the money supply, rendering it unable to provide lender of last resort functions (Cohen 2004). As a result, redenominations often occur after economic crises as governments attempt to convince citizens and markets that hyperinflation is a thing of the past. In some cases, if the timing is correct in that redenomination, it will cap off high levels of inflation. In other cases, governments are not able to rein in inflation immediately after redenomination, and they may make multiple efforts at currency reform. Argentina and Brazil during the 1980s and early 1990s exemplify this pattern (Mosley 2005:1). Oluba (2008) indicates that Redenomination may also present a false resolution of the problems of monetary illusion which is associated with many zeroes and attendant loss of credibility in the currency. With inflation, there is a false feeling of abundance as monetary units become higher.

According to New York representative of Central Bank of Turkish Republic Özçay (2006), deleting zeros from the Turkish Lira has eliminated the technical as well as operational problems that rise from the use of figures with multiple zeros. Therefore, monetary expressions have been simplified hence it becomes easier to take records and make transactions. In sum, the changeover to New Turkish Lira was necessary both for the prospective positive effects on the currency's reputation and for technical reasons. He also states that eliminating 6 zeros from the Turkish Lira has been contributing not only the prestige of the currency in Turkish Citizens' eyes but also on the international level as well. By doing this operation, the trust of people in our currency has been renewed; and this trust creates substantial investment that is increased in financial instruments and is issued in New Turkish Lira.

Much of the literature on currency redenomination focuses on its macroeconomic level issues. These include the reasons of one country to resort to redenomination while others will not pay attention on this certain factor yet considering those which whether or not will make the exercise to succeed or fail. There is hardly any impact on the micro level. Evidence from micro level studies suggests that consumers re-evaluate their management strategies in order to adapt to a newly introduced currency especially when the new and old currencies are used simultaneously, pending a phase-out of the old currency at a later date (Dzokoto and Mensah, 2010:13). Al and Özyurt (2008) investigate the effects on the attitude and behavior of consumers of the operation in deleting zeros from Turkish Liras. Their empirical findings suggest that reputation of New Turkish Liras has increased through the redenomination operation but it hasn't had an important effect on the psychological and economical expectations. Marques and Dehaene (2004) examined on how numerical intuition for prices develops after a major change occurs in currency. There are in accordance to a relearning hypothesis, considering that price estimates become progressively more accurate by a process that is related to buying frequency and, hence, is faster for frequently bought items. Based on this, 2 major processes can occur when a country is adapting to a new currency: rescaling (transforming all prices in the old currency to values in the new currency at the same time) or re-learning (memorize the new prices of consumer goods one by one). The first process would predict an easy adjustment to a new currency, whereas the second process lends itself to a slower, more cumbersome process. The Money/Euro Illusion theory highlights the perception of prices in a smaller denomination new currency lower than when expressed in the former national currency if it had a higher nominal value (Gamble, Garling, Charlton \& Ranyard, 2002) This suggests that individuals who adjust to a new currency with a smaller nominal value will initially, at least, have trouble in understanding the true value of goods and services. (Dzokoto and Mensah, 2010:13).

Şen and Keskin (2004), Tarhan (2006), identifies costs and risks of redenomination as following; (i) inflationary effects of rounding prices, (ii)Changing prices in labels/ menus/ catalogs (iii)Changing laws/regulations (iv) Changing balance sheets/accounting records (v) Changing software 
In addition to these risks of redenomination Oluba (2008) also indicates the risk of choosing a wrong redenomination ratio. If the rate of post-redenomination inflationary growth is not properly estimated - which should be the case because of many reasons which comprise our loose fiscal disposition, poor understanding of the true monetary transmission mechanism, use of incorrect inflation index which does not incorporate changes in prices in instruments traded in several markets such as the capital markets - there is a tendency to either choose a ratio that may be incorrect.

\section{Methodoly Research}

Type of data that is used in this research is secondary data in which is obtained through Inflation data from the World Bank, World Development Indicators annual percent change in consumer prices index, Nation Master, and The Economist Intelligence Unit's index of democracy. Necessary data in this research covers inflation, exchange rate and form of government which are used as redenomination variable.

Analysis of data consists of the influence of inflation rate against action monetary redenomination of cover influence redenomination against inflation, influence redenomination against form of government and influence redenomination against exchange rate. The analysis which is covered is analysis of logistic regression. According to the research, method of data analysis is done, descriptive analysis, analysis of logistic regression and hypotheses test

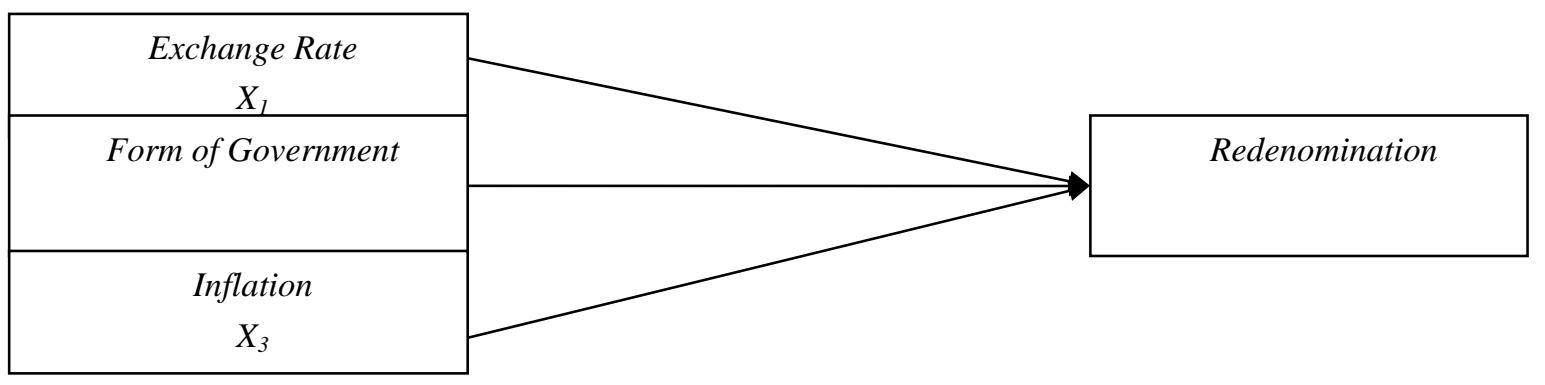

Figure 1. Research Model

\section{Empirical Evidence for the Effect of Redenomination}

Based on the existing data, it will be tested by using descriptive statistics. Where will descriptive statistics show a picture of a data to be examined? The descriptive data includes the average, maximum and minimum values, standard deviation values of all variables to be analyzed. Descriptive statistical results of the processing variables that are used in this study are presented in Table 1 below:

\begin{tabular}{lrrrrr}
\hline & N & \multicolumn{1}{c}{ Min } & Max & \multicolumn{1}{c}{ Mean } & \multicolumn{1}{c}{ Std. Dev } \\
\hline Redenomination & 36 & 0 & 1 & .69 & .467 \\
Exchange Rate & 36 & .06 & 7102.00 & 327.12 & 1254.59 \\
Form Of Government & 36 & 1 & 4 & $2: 58$ & .874 \\
Inflation & 36 & 2.570 & 7481.66 & 661.30 & 1482.52 \\
\hline Valid N ( wise list ) & 36 & & & & \\
\hline
\end{tabular}

Table 1. Descriptive Statistics

The Hosmer-Lemeshow test the null hypothesis that there is a linear relationship between predictor variables and the log odds criterion variable By looking at the goodness of fit test value which is measured by Chi-Square value at the bottom of the test Homser and Lemeshow

The probability is 0.323 which means that regression model is feasible for the use of further analysis. $\mathrm{H}_{0}$ is a linear relationship with variable criteria Predictor variables. Simultaneously, all factors that exist in these variables affect the redenomination. When a country wants to do redenomination, it will consider three important variables, which are: exchange rate, inflation, and form of government.

Results for partial effects are as follows:

\begin{tabular}{llrrrrrr}
\hline & & \multicolumn{1}{c}{ B } & \multicolumn{1}{c}{ S.E. } & \multicolumn{1}{c}{ Wald } & df & \multicolumn{1}{c}{ Sig. } & \multicolumn{1}{c}{ Exp (B) } \\
\hline Step 1 (a) & Exchange Rate & .001 & .001 & 1.637 & 1 & .201 & 1.001 \\
& Form Of Government & -1.196 & .776 & 2.378 & 1 & .123 & .302 \\
& Lg inflation & -8.301 & 4.651 & 3.185 & 1 & .074 & .000 \\
& Constant & 6.995 & 3.644 & 3.684 & 1 & .055 & 1090.771 \\
\hline
\end{tabular}

Table 2. Inference Statistics 
By using $t$ test, the end of the output will show that only inflation is statistically significant in a significant point of view and has affected the decision to do redenomination. Likewise, with a Form of Government, it can affect whether a country will conduct or drop a decision to do redenomination.

In countries where hyperinflation has occurred, the government faces uphill battle to gain the trust of international and domestic markets. According to Mosley, 2005 the most direct means is through stabilization program which is involved by using generally either exchange rate-based or-oriented monetary targeting; increasing the operational independence of the central bank; and removing distortionary economic policies. Countries with the need to do redenomination in May 1970 again have this need in 1980. The hazard of estimation also leaves open the possibility, again, for political considerations to affect redenomination: once the redenomination dam has been broken, it becomes a more viable political option. This assertion Could Be tested in future work by using case studies of (the consideration of) redenomination, as well as assessing public opinion data before and after Various Rounds of redenomination (or in countries with similar economic problems, but with more or less redenomination experience).

The results of this study generate a hypothesis about the factors that influence a government decision to do the redenomination. Of the three independent variables, the most dominant effect is on inflation. It also could indicate that other factors apart from the factor of inflation. Political factors also influence a country whether or not to do redenomination. The predictor of a country in doing redenomination is inflation in the year prior to redenomination period.

\section{Conclusion}

Based on regression analysis that has been examined, the driving factors of redenomination are as follows: (1) Simultaneously, exchange rate, inflation, and from of government influence driving factors of redenomination. (2) Partially, inflation is the most dominant driving factor towards the redenomination. While the exchange rate as well as form of government are the driving factors that do not influence significantly towards redenomination.

\section{References}

- $\quad$ Ajayi, I. (2007): "Preliminary Comments on the new Policy Announced by the Governor of the Central Bank of Nigeria”, Saturday Tribune, available at http://www.tribune.com.ng/08092007/biznes.html

- Aziz, Reuben. 2007. "The Redenomination of The Ghanaian Currency, The Cedi A study of its impact on the business of the Financial Institutions in Ghana ." Master Thesis. http://www.bth.se/fou/cuppsats.nsf (accessed on 7 Desember 2010)

- Brussels. 1997. “The Impact of The Introduction Of the Euro on Capital Markets.” Euro Paper. http://ec.europa.eu/ (accessed on 8 November 2010)

- Cohen, B. (2004): The Future of Money, Princeton University Press, Princeton

- Dogarawa, Ahmad Bello. 2007. "The Economics of Currency Redenomination: An Appraisal of CBN Redenomination Proposal." Munich Personal RePEc Archive.http://mpra.ub.uni-muenchen.de (accessed on 8 October 2010)

- Exchange Rate.2010." Official exchange rate LCU per US\$, period average (most recent) by country." http://www.nationmaster.com/ (Accessed on 29 November 2010)

- Inflation. 2010. “Consumer Price Index.” http://econ.worldbank.org/ ( accessed on 10 October 2010)

- International Economic. 2010. "Historical Exchange Rate Brazil." http://intl.econ.cuhk.edu.hk/exchange_rate_regime/index.php?cid=18 (Accessed on 3 Desember 2010)

- Kekic, Laza. 2008“ The Economist Intelligence Unit's Index of Democracy.” The World.http://graphics.eiu.com/PDF/Democracy\%20Index\%202008.pdf ( accessed on 29 November 2010.)

- Kontan. 2010. "BI Gelar Konpres Soal Redenomasi." http://klasik.kontan.co.id (accessed on 3 August 2010)

- Martinez, I. (2007): "Reflections from Latin America: Can New Currency Abate Venezuelan Inflation, Library of Economics and Liberty", at http://www.econlib.org/

- Mas (1995), Fundamental aspect of Currency Redenomination, http://www.reconversionbcv.org.ve/englishversion/pdf/fundamentalscurrencyredenomination.pdf. (accessed on13 December 2010)

- Mosley, Layna. 2005. "Dropping Zeros, Gaining Credibility? Currency Redenomination in Developing Nations." Paper presented at the 2005 Annual Meetings of the American Political Science Association, Washington, DC. http://convention2.allacademic.com/ (accessed on 23 September 2010).

- Nigeria’s Naira Redenomination Strategy. 2007. " Lead Capital Limited.” http://www.valuefronteira.com/ (accessed on 1 December 2010) 
- Özçay, Akil, 2006, New Turkish Lira http://www.tcmb.gov.tr/yeni/banka/yenilira/NewTurkishLira.pdf (accessed on 22 May 2011)

- Rosser Andrew, 2005. “Laos .” Asian Development Outlook. http://siteresources.worldbank.org/ (accessed on13 December 2010)

- Tarhan, 2006 http://www.vostroknutov.com/pdfs/teaching/2008spring/glslides.pdf

- Wibowo, Weni Hermanto. 2004. “Analisis Pergerakan Nilai Tukar Rupiah Terhadap Dollar Amerika Setelah Diterepkannya Sistem Nilai Tukar Mengambang Bebas.”Skripsi. http://digilib.petra.ac.id/ (accessed on 1 December 2010)

- Wikipedia. 2010. "Form Of Government." http://en.wikipedia.org/wiki/Form_of_government (accessed on 1 December 2010) 